\title{
Iron and steel varieties between 1860 and 1914: survey of the Belgian nomenclature
}

\author{
M. de Bouw ${ }^{1}$, I. Wouters ${ }^{1}$, J. Vereecken ${ }^{2} \&$ L. Lauriks ${ }^{1}$ \\ ${ }^{I}$ Faculty of Engineering Sciences, Department of Architectonic \\ Engineering Sciences (ARCH), Vrije Universiteit Brussel, Belgium \\ ${ }^{2}$ Faculty of Engineering Science, Department of Materials and Chemistry \\ (MACH), Vrije Universiteit Brussel, Belgium
}

\begin{abstract}
Iron has been known for many centuries. In the course of the 19th century, the metal production methods evolved quickly, which resulted in many different varieties of iron and steel being in use during the same period. Unfortunately, when turning to historic literature, the nomenclature used to designate the type of iron or steel and the corresponding properties are far from uniform and clear.

This paper discusses the development during the period 1860-1914, as during this time many different metals were used simultaneously. The research focuses especially on the situation in Belgium, as it is particularly interesting due to the Flemish-French linguistic problem and the clash of the English, French and German influences.

The paper provides an overview of the original French and English nomenclature. By highlighting common misunderstandings, the relevance for today's practice is illustrated.

Keywords: iron, steel, terminology, nomenclature, survey, Belgium, French, English.
\end{abstract}

\section{Introduction}

Past research has revealed serious shortcomings concerning the terminology and properties of ancient structural ferrous-metals. When reading historic steel manuals, one finds many terms referring to the different iron and steel varieties. Between 1860 and 1914, ferrous-metals in the building industry evolved quickly. A vast range of ferrous-metals with widely divergent characteristics was 
produced and was used simultaneously. This industrialisation and evolution of production techniques resulted in new (unproven) materials and construction and calculation methods. However, when trying to gain insight to the functioning of metal structures and their bearing capacity, it is indispensable to know exactly which materials were available in one specific period and how the nomenclature evolved in time.

The survey focuses especially on the Belgian building industry. The Belgian situation is particularly interesting, in first place because of the specific geographic location of the Belgian territory. As Belgium lies between France, England and Germany, many Belgian engineers and regulations were inspired and influenced by the customs of these surrounding countries. The second interesting aspect about the Belgian situation is due to the French-Flemish linguistic problem. The first Flemish engineering manuscripts were in fact Dutch manuscripts. These were not used in Belgium until circa 1910. Before that date, the official language for Belgium was French. The outcome is that, for a long and important period in the evolution of the metal production, we did not have a Flemish terminology, corresponding to that of the rich French language.

At present, no scientific survey exists to elucidate this situation. Considering this lack of information, this research clarifies the situation in Belgium during the period 1860-1914.

The research is based on the most important and widespread Belgian construction and calculation manuscripts dealing with iron and steel constructions, written in 1850-1937. These 31 guidebooks (see references 1 to 31 ) were analyzed and compared to each other and to modern literature (see references 33 to 37 ).

\section{Nomenclature according to the production and treatment}

When reading ancient construction manuals, the nomenclature in Belgium between 1860-1914 for ferrous-metals could be divided in to three categories. Depending on the purpose, the authors can refer to:

1. the production and treatment of the metal types,

2. the quality of the metal sort,

3. the form of the metallic elements.

As there is no existing overview and as this is essential for understanding the nomenclature, we produced the three corresponding overviews in French, Flemish/Dutch, English and German. This paper focuses only on the overview of the production and treatment processes, as this is the basis for the other two overviews.

As starting point for the representation of the results, we adopted and completed the diagram by H.M.C.M. Maarschalkerwaart in his article "Slaan, trekken en vloeien" [35]. Besides all the possible original French terms (Figure 1), we provide the English diagram (Figure 2) as well in this paper because these two languages occupy a prominent place. In former days, French was the official medium of communication in Belgium and on international conferences. These days however, the English language occupies the key role as language of communication on international conferences. 


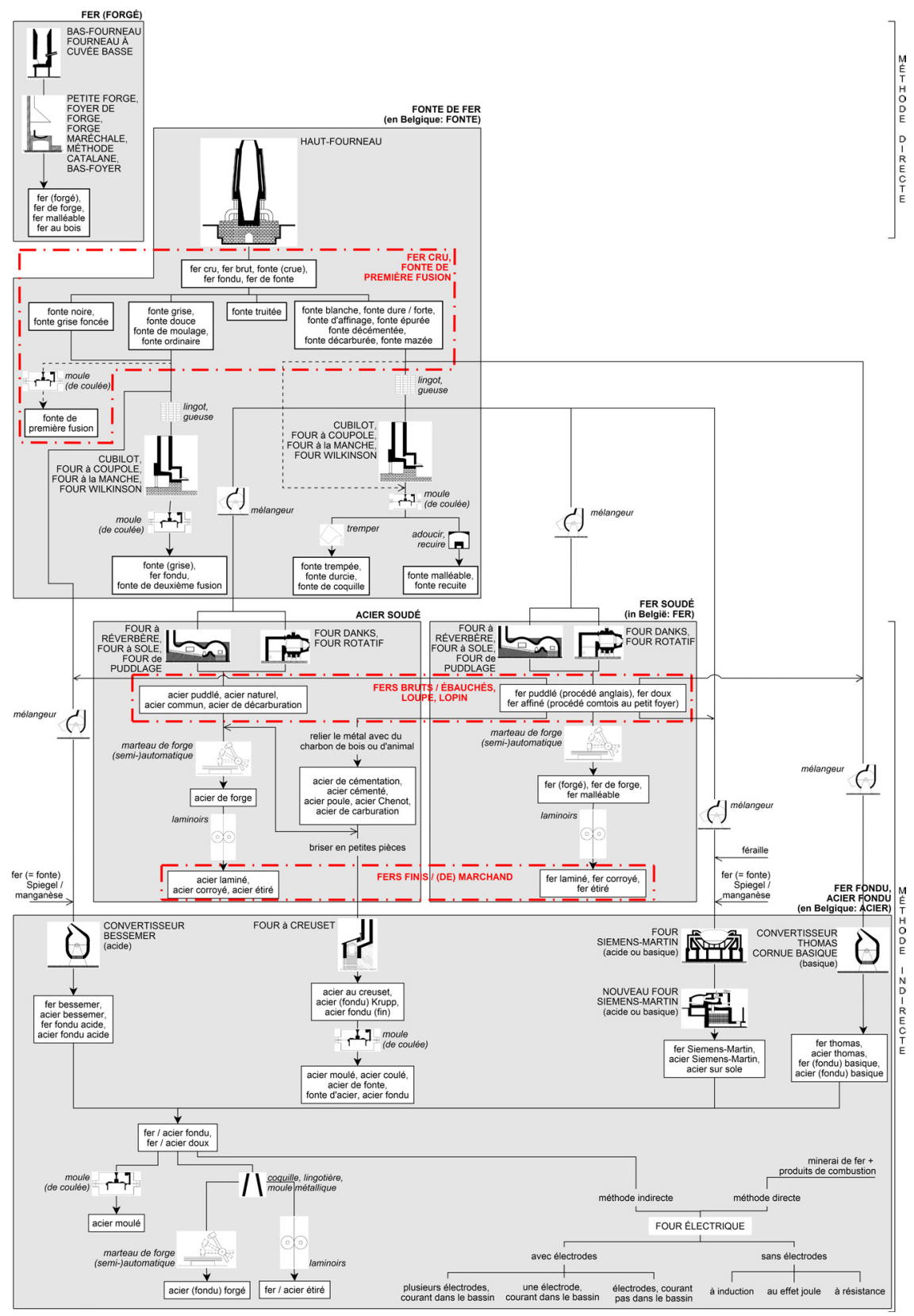

Figure 1: Scheme of the production and treatment processes of iron and steel French nomenclature. 
270 Structural Studies, Repairs and Maintenance of Heritage Architecture X

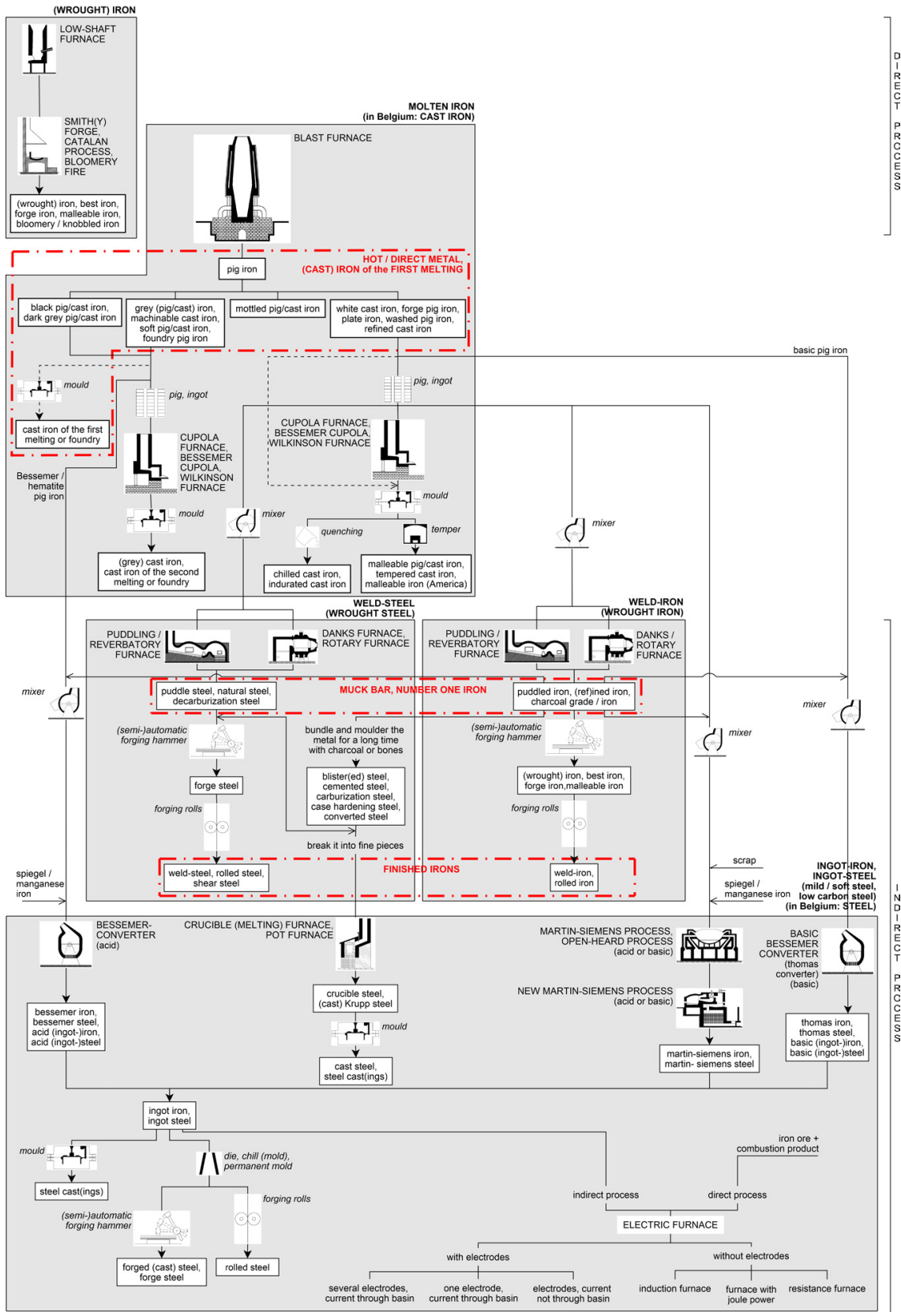

Figure 2: Scheme of the production and treatment processes of iron and steel English nomenclature. 
The diagrams in Figure 1 and Figure 2 represent the production process and the regarding product names of the different iron and steel types that were in circulation in the considered period. The diagrams show the necessary treatments to evolve from fonte de fer (molten iron) (at the top of the diagrams) to different varieties of fer (iron) and acier (steel).

As it is impossible in the scope of this paper to explain in detail the complete diagrams, we preferred go more deeply in to a restricted number of the most important points of interest. To elucidate (the importance of) these schemes, the following four aspects will be illustrated with some examples:

- the introduction of generic names in 1876 ,

- ambiguous designation problems due to ignorance,

- today's problems owing to obsolete expressions,

- $\quad$ present-day misunderstandings due to a change of meaning of words.

\subsection{The introduction of generic names in $\mathbf{1 8 7 6}$}

Due to the invention and introduction of new production processes in the considered period, the terminology of metals became very confusing and difficult to understand, even for experts back then. Therefore, profound discussions to create one general world-wide classification for non-alloyed ferrous building metals started.

S. Jordan and Greinert gave a first proposition [25]. All forgeable metal products that were achieved by fusion should be called acier (steel) and all forgeable metal products that had not undergone fusion, fer (iron). This would mean that the historical acier (steel) - viz acier poule (blister steel), acier naturel (natural steel), acier corroyé (weld-steel), etc - would not be called acier (steel) anymore, but ordinary fer (iron). Moreover, this new nomenclature would not take into account the ability of trempe (hardening) at all.

The International Committee of Metallurgy proposed a new classification of non-alloyed ferrous-metals in 1876 at the Universal Exposition at Philadelphia $[10,14,17,25]$. For the first time in history, such a general classification was accepted and adopted throughout the world. The motion proposed five classes (see grey boxes in Figure 1 and Figure 2):

1. fonte de fer (molten iron) - any type of fer cru (pig iron) that is used for casting, without any further treatment except of the haut-fourneau (blast furnace) and possibly the cubilot (cupola furnace),

2. fer soudé (weld-iron) - any type of fer malléable (forgeable iron) that did not undergo fusion (by consequence the structure is not homogeneous), nor is susceptible to hardening (until that day called fer doux (wrought-iron)),

3. acier soudé (weld-steel) - any type of fer malléable (forgeable iron) that did not undergo fusion (by consequence the structure is not homogeneous), but is susceptible to hardening (until that day called acier naturel (natural steel), acier de forge (forge steel) or acier puddlé (puddle steel)), 
4. fer fondu (ingot-iron) - any type of fer malléable (forgeable iron) that did undergo fusion (by consequence the structure is homogeneous), but is not susceptible to hardening,

5. acier fondu (ingot-steel) - any type of fer malléable (forgeable iron) that did undergo fusion (by consequence the structure is homogeneous) and is susceptible to hardening.

At the conference, they agreed that these names were generic names, covering (and not replacing) the specific names of different types of iron and steel.

Unfortunately, the introduction of these names led to some problems when reading ancient books, as (especially in Belgium) some engineers, metallurgists, smiths and authors still held on to their traditional names, and because (worldwide) some terms already had a different meaning before the introduction of these generic names.

\subsubsection{Specific Belgian linguistic usage problems}

Notwithstanding the convention of 1876, most of the Belgian engineers, smiths, authors and metallurgists kept using their old, habitual names.

This explains for instance why the diagrams (Figure 1 and Figure 2) only show four grey boxes instead of five, as agreed during the convention of 1876 . In Belgium, no difference was made between the generic terms fer fondu (ingotiron) and acier fondu (ingot-steel). Both were simply called acier (steel). If they wanted to indicate a difference, they had to take recourse to the terms used to designate the quality, with fer fondu (ingot-iron) having a lower carbon percentage than acier fondu (ingot-steel).

The generic expression fer soudé (weld-iron) was not adopted either in Belgium. To indicate this type of iron, the collective names fer (iron) or fer doux (mild steel) were used. However, fer (iron) can also be used to specify (1) the products of the smithy forge, (2) the specific fer soudé (weld-iron) that has been hammered, (3) all structural metal elements in general or (4) all structural metal elements with a carbon percentage below 0.2. On the other side, fer doux (mild steel) can also indicate (1) the specific iron that comes out of the four $\grave{a}$ réverbère (reverbatory furnace) or (2) the fer fondu (ingot-iron) that comes out of the convertisseur Bessemer (Bessemer converter), four Siemens-Martin (openheard process) or the convertisseur Thomas (basic Bessemer converter).

The expression fer de fonte (pig iron) indicates the iron that comes right out of the haut-fourneau (blast furnace). On the other hand, the term fonte de fer (molten iron) is the generic name for any type of fer de fonte or fer cru (pig iron) that is used for casting, without any further treatment except of the hautfourneau (blast furnace) and possibly the cubilot (cupola furnace). To cause total confusion on this matter, Belgium just used the name fonte (cast iron). This term can point to (1) fonte de fer (molten iron), (2) fer de fonte (pig iron) or (3) fonte grise de deuxième fusion (grey cast iron of the second melting). 


\subsubsection{Terms already having a different meaning before the introduction of the generic names in $\mathbf{1 8 7 6}$}

Besides the problems corresponding to the terms fer fondu (ingot-iron) and acier fondu (ingot-steel) mentioned in section 2.1.1, the introduction of these expressions in 1876 as generic names caused some confusion too.

The name fer fondu (ingot-iron), for example, was in circulation long before 1876 , but had a total different meaning. Before that date the term fer fond $u$ was used to denote the specific product (1) fer de fonte (pig iron) that comes right out of the haut-fourneau (blast furnace) or (2) fonte grise de la deuxième fusion (grey cast iron of the second melting). As the production process of these three materials is totally different, the properties of these three materials are too.

\subsection{Ambiguous designation problems due to ignorance}

Due to the permanent and quick evolution of metal production techniques and a lack of international coordinating standardization organisations, some terms indicating a specific product got ambiguous designations in the course of time.

For example, when reading about acier moulé (steel cast), one has to know that this term can indicate two 'different' metals. Both of them are classified under the group of fer fondu (ingot-iron) and acier fondu (ingot-steel). However, the followed production method is totally different, and as a consequence the resulting product too. To explain this, we will summarize the production process of both materials.

To create the first type of acier moule (steel cast), one of the three types of iron or steel that comes out of the convertisseur Bessemer (Bessemer converter), four Siemens-Martin (open-heard process) or convertisseur Thomas (basic Bessemer converter) has to be produced. This fluid material is then cast into a moule (mould) to create the desired construction element. By this, an element in fer fondu (ingot-iron) or acier fondu (ingot-steel) can be created, depending on the length of the refining in the furnace, and as a consequence the percentage of carbon, as with these procedures the quality is highly verifiable, even during the process of refining.

On the other hand, it is also possible to create acier moulé (cast steel) from the four à creuset (crucible furnace). Until 1860, this procedure was mostly used in Belgium to create acier (steel). There are two possibilities to produce this sort of steel. In the first way, the acier puddle (puddled steel) from the four à réverbère (reverbatory furnace) is broken in to little pieces and put in the four à creuset (crucible furnace). However, this type of steel is only produced until 1902 in Belgium [10]. The other possibility is to bundle the loupes (muck bars) of fer puddlé (puddled iron) of fer affiné (refined iron) and moulder them for a long time with charcoal or bones to increase the carbon percentage to produce acier de cémentation (blister steel). This acier de cémentation (blister steel) is then broken in to little pieces and put in the four à creuset (crucible furnace). Both ways, the acier (steel) for the four à creuset (crucible furnace) is put in to pots (pots) to melt it and avoid contact between the combustion products and the broken steel pieces, so that the carbon percentage is not altered anymore. Once it is molten, it is cast into moules (moulds) to produce acier moulé (cast steel). 
This difference in production methods means that the acier moulé (cast steel) from the four à creuset (crucible furnace) will always be acier fondu (ingotsteel) and never fer fondu (ingot-iron), contrary to the acier moulé (steel cast), produced by convertisseur Bessemer (Bessemer converter), four Siemens-Martin (open-heard process) or convertisseur Thomas (basic Bessemer converter). In addition, the resulting quality of latter procedure is easier to follow up, as the production of blister steel is very experimental and depending on the quality of the starting product, the amount and size of the bundled pieces and charcoal/bones, and the length of the carburization.

\subsection{Today's problems owing to obsolete expressions}

When reading about fer affiné (refined iron) and fer puddlé (puddled iron) it is important to know there is a difference between these two products and terms, although both products are fers ébauchés (muck iron) from the four à réverbère (reverbatory furnace) or the four Danks (Danks furnace).

During the considered period, not only new products were invented, but people also experimented with new combustion products. In former times, the use of charcoal was generally adopted. However during the first industrialization, as wood became scarce in some regions, people begun to experiment with cokes as combustion product.

Cokes were neither widespread nor well-known at the beginning of the considered period. Therefore, many engineers proclaimed the superiority of charcoal and even the (very) bad quality of metals produced with cokes, even until 1888 [21, 28]. However, others noticed the irreversible rise and possibilities of cokes already in 1873 [27]. As from 1897, merely cokes were used across Belgium [14]. Until that day, engineers referred to fer affiné (refined iron) if charcoals were used to refine the iron, and to fer puddlé (puddled iron) if cokes were used.

\subsection{Present-day misunderstandings due to a change of meaning of words}

Manuals from the considered period often mention the soudabilite (capability of being weld) of metals in function of the structure and contaminants that are present. However, it is important to notice that the former sense of the word soudabilité (capability of being weld) is very different from the present one.

In former days, souder (to weld) denoted the possibility of joining two pieces of metal together by means of pressure. The two pieces were warmed up until a specified temperature and then combined to one element by hammering them together. Some of the possible welds are shown in Figure 3. If this technique was not possible, the only possibility was to solder the pieces with lead or tin.

Nowadays, when speaking of souder (to weld), we commonly suppose the technique of metallic/electric arc welding. However, this technique was not used before 1881. That year, for the first time in history, a metallic arc weld was performed in France [15]. Nevertheless, this process did not experience a mushroom growth until W.W. II. 

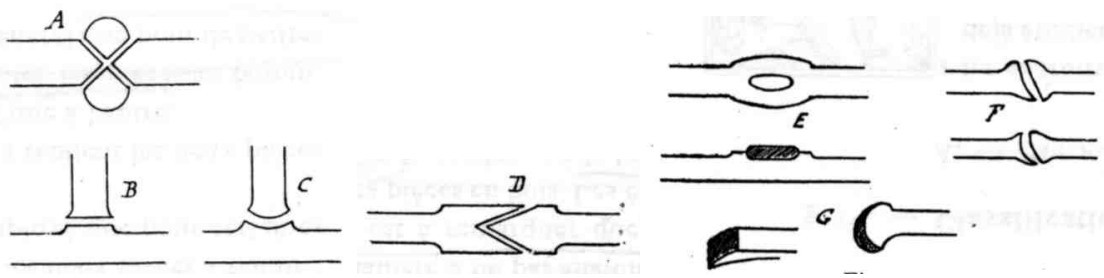

Figure 3: $\quad$ Some possible forms of historic pressure welding [15].

\section{Conclusions}

In an era of continual internationalization and growth of awareness for the re-use of cultural heritage, engineers often get confronted with specific historical terms that describe vast range of metallic materials. However, as there was at that time no international coordinating organization controlling the nomenclature, choosing a proper equivalent and translating these terms from French into English (and vice versa) is not evident these days. This applies especially for the terminology of non-alloyed ferrous-metals, produced between 1860 and 1914 .

In order to clarify this confusing situation, one of the most important moments in time concerning the nomenclature of iron and steel products, was the Conference on Metallurgy at the Universal Exposition at Philadelphia in 1876.

Before this convention, engineers, authors, smiths, etc used ambiguous terminologies out of ignorance to describe their metallic materials. In a response to this indistinctness, the International Committee of Metallurgy proposed a new classification of non-alloyed ferrous-metals, that should have been adopted world-wide to elucidate the terminology in different countries and languages.

However, these new categorizations still raised confusion, because the terms of the new generic names had a different meaning before the introduction of these generic names and because some engineers, authors, smiths, etc - certainly in Belgium - stuck to their old traditional terms.

Beside this 're-categorization' and the resulting ambiguous terminology, some expressions simply faded away, because the corresponding material or production process fell into disuse, and others got a new meaning throughout time.

In the scope of the problems mentioned in this paper and the different characteristics of the materials, it is important to possess production diagrams in different languages and link them to a timetable to get an overview of what materials were used in which country and at what time.

\section{Acknowledgement}

This research project is funded by the "Fonds voor Wetenschappelijk Onderzoek". 


\section{References}

[1] Nachtergal, A., Charpentes métalliques - Calculs et construction. 5 ed.; Editions Bieleveld: Brussel, 1937; 1004 p.

[2] Van Der Veen, H. J. \&. W. A., IJzerconstructies. 4e ed.; Boekhandeluitgeverij 'De Techniek' / L. J. Veen: Amsterdam-Antwerpen, 1919; 424 p.

[3] Zwiers, L., Handboek der burgerlijke bouwkunde: deel III IJZERCONSTRUCTIES. N.V. Uitgevers-maatschappij v/h. Van Mantgem \& De Does: Amsterdam, 1916; 363 p.

[4] Nachtergal, A., Charpentes métalliques - Calculs et construction. Victor Adam: Morlanwelz, 1912; Vol. 1, 24 p.

[5] Aerts, L., Eléments pratiques de la résistance des matériaux. 4 ed.; J. Wouters-Ickx - Ch. Béranger: Leuven-Parijs-Luik, 1911; 417 p.

[6] Renaud, V., Théorie des Alliages et Notions de Métallographie. In Gent, 1911, pp 94-102.

[7] Barberot, E., Traité pratique de charpente. Librairie Polytechnique Ch. Béranger: Parijs-Luik, 1911; 600 p.

[8] Francken, D., La construction civile - Les matériaux et leur mise en oeuvre. Imprimerie "De Vlijt": Antwerpen, 1910; 753 p.

[9] Howe, M., Sauveur, A., "Über die einheitliche Nomenklatur von Eisen und Stahl". Internationaler Verband für die Materialprüfungen der Technik - V. Kongress, Kopenhagen 1909, pp VIII2/1-VIII2/24

[10] Vierendeel, A., La construction architecturale en fonte, fer et acier. Brussel-Leuven-Parijs, 1902; 879 p.

[11] Cloquet, L., Traité d'Architecture. Librairie Polytechnique Baudry et Cie: Parijs-Luik, 1898; Vol. 1 \& 2.

[12] Flamant, A., Stabilité des constructions - Résistance des matériaux. Librairie Polytechnique Baudry et Cie: Parijs-Luik, 1897; 674 p.

[13] Combaz, P., La construction: principes et applications. J.-G. Pieper - Ch. Desoer - H. Dunod \& E. Pinat: Brussel - Luik - Parijs, 1897; Vol. 3 - Part 7, $290 \mathrm{p}$.

[14] Combaz, P., La construction: principes et applications. E. Lyon-Claesen: Brussel, 1897; Vol. 2 - part 3 \& 4.

[15] Combaz, P., La construction: principes et applications. E. Lyon-Claesen: Brussel, 1895; Vol. 1 - part 2, 441 p.

[16] Delporte, J., Formules et tableaux pratiques. H. Vaillant-Carmanne: Luik, $1895 ; 134 \mathrm{p}$.

[17] Van Drunen, J., L'acier dans la construction. Charles Rozez: Brussel, $1892 ; 312$ p.

[18] Launoy, J., Le guide du praticien Belge dans les Constructions civiles. Imprimerie Aug. Fonteyn: Leuven, 1890; 410 p.

[19] Vierendeel, A., L'architecture métallique au XIXe siècle et l'exposition de 1889, à Paris. Librairie Scientifique, Industrielle et Agricole E. Ramlot: Brussel, 1890; 99 p. 
[20] Dechamps, H., Les principes de la construction de charpentes métalliques. Imprimerie H. Vaillant-Carmanne: Luik, 1888; 390 p.

[21] Barberot, E., Traité pratique de serrurerie - Constructions en fer. Librairie Polytechnique, Baudry \& Cie: Luik, 1888; 393 p.

[22] Boudin, E., Notes sur le cours de stabilité. Gent, 1887; Vol. 2.

[23] Aerts, L., Eléments pratiques de la résistance des matériaux. Aug. Fonteyn: Leuven, 1886; 211 p.

[24] De Vos, N., Cours de construction donné de 1864 à 1874 à la section du génie de l'école d'application de Bruxelles. Librairie Polytechnique de Decq \& Duhent: Brussel, 1879; Vol. 1 (455 p) \& Vol. 2 (463 p).

[25] Gruner, L., "N³6 - Note sur le vrai sens des mots FER et ACIER". Annales des ponts et chaussées - mémoires et documents 1877 ( $5^{\mathrm{ième}}$ série, tome XIII, $1^{\text {ier }}$ semestre), pp 505-508.

[26] Moerman, C., Traité des construction civiles. 2 ed.; Brussel, 1876; 288 p.

[27] Boudin, E., Cours de technologie professé à l'école spéciale du génie civil et des arts et manufactures. Hoste: Gent, 1873; Vol. 1.

[28] Château, T., Technologie du bâtiment ou étude complète des matériaux de toute espèce employés dans l'art de bâtir. Morel: Parijs, 1866; Vol. 2, 289 p.

[29] Law, H., Manuel pratique de construction. Stapleaux: Brussel, 1850; 84 p.

[30] Demanet, A., Cours de construction professé à l'école militaire de Bruxelles (1843 à 1847). Delevingne et Callewaert: Brussel, 1850; 560 p.

[31] Matheson, E., Works in Iron. 1873; pp 296-331.

[32] Van de Vijver, D. In From Nieuport to Magnel: An institutional history of building science in Belgium, 1780-1930, First International Congress on Construction History, Madrid, Huerta, S., Ed. Instituto Juan de Herrera, Madrid, 2003, pp 2055-2063.

[33] De Sy, A., Beginselen van algemene metallurgie en siderurgie. NICI: Gent, 1965; 364 p.

[34] Friedman, D., Historical Building Construction - Design, materials and technology. W.W. Norton \& Company: New York, London, 1995; 238 p.

[35] Maarschalkerwaart, H. M. C. M., "Slaan, trekken en vloeien". Bouwen met staal 1996 (januari/februari), pp 28-35.

[36] In Réhabilitation des ouvrages en acier, Parijs, CTICM \& OTUA, Parijs, 2004.

[37] Walker, B. Corrugated iron and other ferrous cladding. TAN 29, Historic Scotland - Technical Conservation, Research and Education Division: Edinburgh, 2004, 54 p. 